Sanet Janse van Vuuren, Gerhard du Preez, Anatoliy Levanets, and Louis Maree. Epilythic cyanobacteria and algae in two geologically distinct caves in South Africa. Journal of Cave and Karst Studies, v. 81, no. 4, p. 254-263. DOI:10.4311/2019MB0113

\title{
EPILYTHIC CYANOBACTERIA AND ALGAE IN TWO GEOLOGICALLY DISTINCT CAVES IN SOUTH AFRICA
}

\author{
Sanet Janse van Vuuren ${ }^{1}, \mathrm{c}$, Gerhard du Preez ${ }^{1}$, Anatoliy Levanets ${ }^{1}$, and Louis Maree ${ }^{1}$
}

\begin{abstract}
There is a lack of knowledge on cyanobacteria and algae living in caves in the southern hemisphere. As a result, a pioneer study was undertaken to investigate cyanobacterial and algal community composition in two morphologically and geologically distinct caves in South Africa. Skilpad Cave is characterized by a large sinkhole entrance in a dolomitic landscape. Three zones (light zone, twilight zone and dark zone) were identified based on differences in light intensity. Bushmen Cave, on the other hand, is a rockshelter overhang situated in a sandstone-dominated area and only presents a light and twilight zone. Cyanobacteria and algae were sampled twice, during the summer and winter of 2018 while abiotic factors of interest, i.e. light intensity, temperature and relative humidity, were also measured. A huge diversity of cyanobacteria (14 genera) and algae (48 genera) were identified in the two caves. While some genera were only present in one of the caves, other cosmopolitan genera were found in both caves. The most common genera encountered were Phormidium, Oscillatoria and Nostoc (cyanobacteria), Pinnularia and Luticola (diatoms), Chlorella and Chlorococcum (green algae). Cyanobacteria, green algae and diatoms were also the richest groups (taxa) in terms of the number of genera. More genera were present in the warm, wet season compared to the dry, cold season. Genus richness was positively correlated with light intensity in Skilpad Cave, but negatively in Bushmen Cave. Petalonema alatum, a cyanobacterium encountered in Bushmen Cave, represented a new record for Africa, and therefore, further research on cyanobacteria and algal assemblages in caves in the southern hemisphere is strongly recommended.
\end{abstract}

\section{Introduction}

Researching the biology of caves not only presents an opportunity to study unique and extreme ecosystems, it is also fundamental to our understanding of earth's delicate ecological balances (Lee et al., 2012). Caves typically represent extreme environments characterized by low nutrient availability (Pedersen, 2000), a limiting factor for many biota. However, some lifeforms, including cyanobacteria and algae, still find such environments suitable for colonization and growth (Mulec et al., 2008).

Cave-associated communities of cyanobacteria and algae are mainly influenced by three factors: light, temperature, and humidity (Hernández-Mariné and Canals, 1994; Ducarme et al., 2004; Poulîčková and Hašler, 2007; Lamprinou et al., 2009, 2012). Apart from these factors, water seepage, as well as subterranean characteristics such as cave dimensions, microclimate, morphology, substrate types, and nutrient availability, also influence microbial community colonization and composition (Golubić, 1967; Martinčič et al., 1981; Chang and Chang-Schneider, 1991; Czerwik-Marcinkowska, 2013; Popović et al., 2015).

Based on light intensity, a cave can be divided into three zones, namely the light, twilight and dark zones (Humphreys, 2000). The light zone, usually found at or near the entrance, is subjected to sunlight; and therefore, light intensity, temperature, and relative humidity vary throughout the day. The light zone typically supports various types of microorganisms, plants, and animals (Monro et al., 2018). The twilight zone, characterized by more stable environmental conditions, is exposed to indirect, low light conditions typically insufficient to support complex lifeforms, such as seed plants. Nonetheless, these conditions can sustain some cyanobacteria, algae, mosses, and ferns (Culver and Pipan, 2009). Finally, the dark zone is characterized by the absence of light; and therefore, photosynthetic life. However, specialized algae that utilize alternative metabolic pathways to produce energy have been reported on cave walls (Smarž et. al., 2013; Khan et al., 2016).

Cyanobacteria and algae growing on rock surfaces in aerophytic habitats are known as lithophytes. Of all lithophytes, cyanobacteria are the most adaptable to extreme environments, and together with algae, they usually play an important role in the early phases of colonization and succession (Mulec and Kosi, 2008). Later, these lifeforms may dominate in illuminated karstic cave walls and ceilings (Sambamurty, 2010; Popović et al., 2015).

Due to constant environmental parameters, Mulec et al. (2008) regarded caves as almost ideal natural laboratories. Stable temperature and relative humidity levels, together with the presence of water, particularly favor the growth of cyanobacteria, algae, fungi, mosses, and some ferns. Spores of such biota are carried by wind, migrating animals, and/or water runoff into caves (Falasco et al., 2014; Czerwik-Marcinkowska et al., 2019). Although organic matter can also be carried by water, especially during flooding (Simon et al., 2003; Souza Silva et al., 2011), or be deposited in bat guano

1 Unit of Environmental Sciences and Management, North-West University, Potchefstroom, South Africa

c Corresponding author: sanet.jansevanvuuren@nwu.ac.za 
(Wattez et al., 1990; Kasso and Balakrishnan, 2013), seed plants may be less common in caves due to the lack of sufficient light. They are, therefore, usually limited to the cave entrance (light zone), while the twilight and dark zones are typically marked by less diverse assemblages of cyanobacteria and algae. In general, as the amount of light decreases, the size and complexity of photosynthetic life also decrease (Grobbelaar, 2000; Abdullin, 2011; Lee et al., 2012).

According to Lee et al. (2012), the first microbiological study in caves was undertaken in the late 1940's. Since then, a large number of microbial studies have been undertaken in caves all over the world, especially in the northern hemisphere, and life forms of all kinds have been discovered in various cave systems. Most publications report on the microbial communities associated with caves from European countries, including Czech Republic (Poulîčková and Hašler, 2007), France (Borderie et al., 2011), Greece (Lamprinou et al., 2012), Italy (Cennamo et al., 2012), Poland (Czerwik-Marcinkowska and Mrozińska, 2011), Russia (Gainutdinov et al., 2017), Serbia (Popović et al., 2015, 2017), Slovenia (Mulec and Kosi, 2008), Spain (Busquets et al., 2014), and Turkey (Selvi and Altuner, 2007). In spite of the fact that rare and even new species are often found in caves (Hernandéz-Mariné and Canals 1994; Pipan 2005), a limited number of studies have been conducted on cyanobacterial and algal communities in caves located in the southern hemisphere. An in-depth literature review revealed that only a few phycological studies were documented in caves in South Africa, which were devoted to either cyanobacteria (Büdel et al., 1993; Wessels and Büdel, 1995; Büdel et al., 2004; Maree et al., 2018) or diatoms (Grobbelaar, 2000; Taylor and Lange-Bertalot, 2013).

The aim of this study was to investigate the composition of cyanobacterial and algal communities in different cave zones subjected to varying levels of light intensity, temperature and relative humidity levels. This study represents the first in Africa to include both cyanobacteria and different algal phyla present in caves.

\section{Material and Methods}

\section{Study area}

The study area included a karstic cave (Skilpad Cave) and rock shelter (Bushmen Cave), located $580 \mathrm{~km}$ apart (Fig. 1). These caves were studied during March and July 2018, representing the hot, wet and cold, dry seasons, respectively.

Skilpad Cave (261 '9.04" S; $\left.27^{\circ} 11^{\prime} 46.15^{\prime} \mathrm{E}\right)$ is located at an altitude of $1633 \mathrm{~m}$ above sea level, $50 \mathrm{~km}$ north of the town Potchefstroom (North West province, South Africa), and is visited by a local caving club annually. The cave's entrance (facing South-East) is a sinkhole overgrown with cyanobacteria, algae, mosses, ferns, and trees, in contrast to the surrounding bioregion that consists of dry highland grassland classified as Carletonville Dolomite Grassland vegetation (Mucina et al., 2006). The geology of the surrounding area can be defined as dolomite, subordinate chert, minor carbonaceous shale, limestone, and quartzite (Burger, 2013). The average temperature and total precipitation for this region during March 2018 was $25^{\circ} \mathrm{C}$ and $177.7 \mathrm{~mm}$, respectively. During July 2018 the average temperature and total precipitation decreased to $15^{\circ} \mathrm{C}$ and $7.6 \mathrm{~mm}$, respectively (World Weather Online, 2018). Bats inhabit this cave and guano is present in deeper areas of the cave. Based on the light exposure classification provided by Lee et al. (2012), three zones of interest were identified, namely the light zone (entrance of sinkhole), the twilight zone (bottom of sinkhole) and the dark zone (first chamber of cave).

Bushmen Cave (28 $34^{\prime} 28.07^{\prime \prime} \mathrm{S}$; $\left.28^{\circ} 26^{\prime} 15.42^{\prime \prime} \mathrm{E}\right)$ is located at an altitude of $1872 \mathrm{~m}$ above sea level, $9.5 \mathrm{~km}$ southeast of the town Clarens (Free State province, South Africa). It is named after the Bushmen (or San) people and their historic rock art that can be found on the shelter walls. Bushmen Cave is a rock shelter (open North-West facing overhang) used by hikers as an overnight shelter. It is located in the Drakensberg grassland bioregion, which is classified as Lesotho Highland Basalt Grassland vegetation (Mucina et al., 2006). The geology of the area is characterized as sandstone, pink-weathering granular or augen quartz-feldspar gneiss (Johnson 1991; Burger, 2013). The average temperature and total precipitation during March 2018 was $21^{\circ} \mathrm{C}$ and $270.9 \mathrm{~mm}$, respectively. During July 2018, the average temperature decreased to $12^{\circ} \mathrm{C}$ and the total precipitation to $0.8 \mathrm{~mm}$ (World Weather Online, 2018). Following the same light classification by Lee et al. (2012), the entrance was identified as the light zone and the back wall of the shelter as the twilight zone. No dark zone exists in this rock shelter.

In Skilpad Cave a total of 13 sampling sites were selected: five sites were in the light and twilight zones, respectively, while three sites were in the dark zone. In Bushmen Cave, a total of 12 sites were sampled: five sites were situated in the light zone and seven in the twilight zone. Therefore, a total of 25 sites were sampled in the two caves.

\section{Measurement of abiotic factors}

At Skilpad and Bushmen caves, three abiotic factors (light intensity, temperature, and relative humidity) were measured at each site at hourly intervals $(08: 00-17: 00)$ during both sampling intervals. Light intensity $\left(\mu \mathrm{mol} \mathrm{m}^{2} \mathrm{~s}^{-1}\right)$ was measured using a calibrated LI-COR LI-250A light meter, while temperature $\left({ }^{\circ} \mathrm{C}\right)$ and relative humidity $(\%)$ were measured using a TROTEC BL30 climate data logger. 

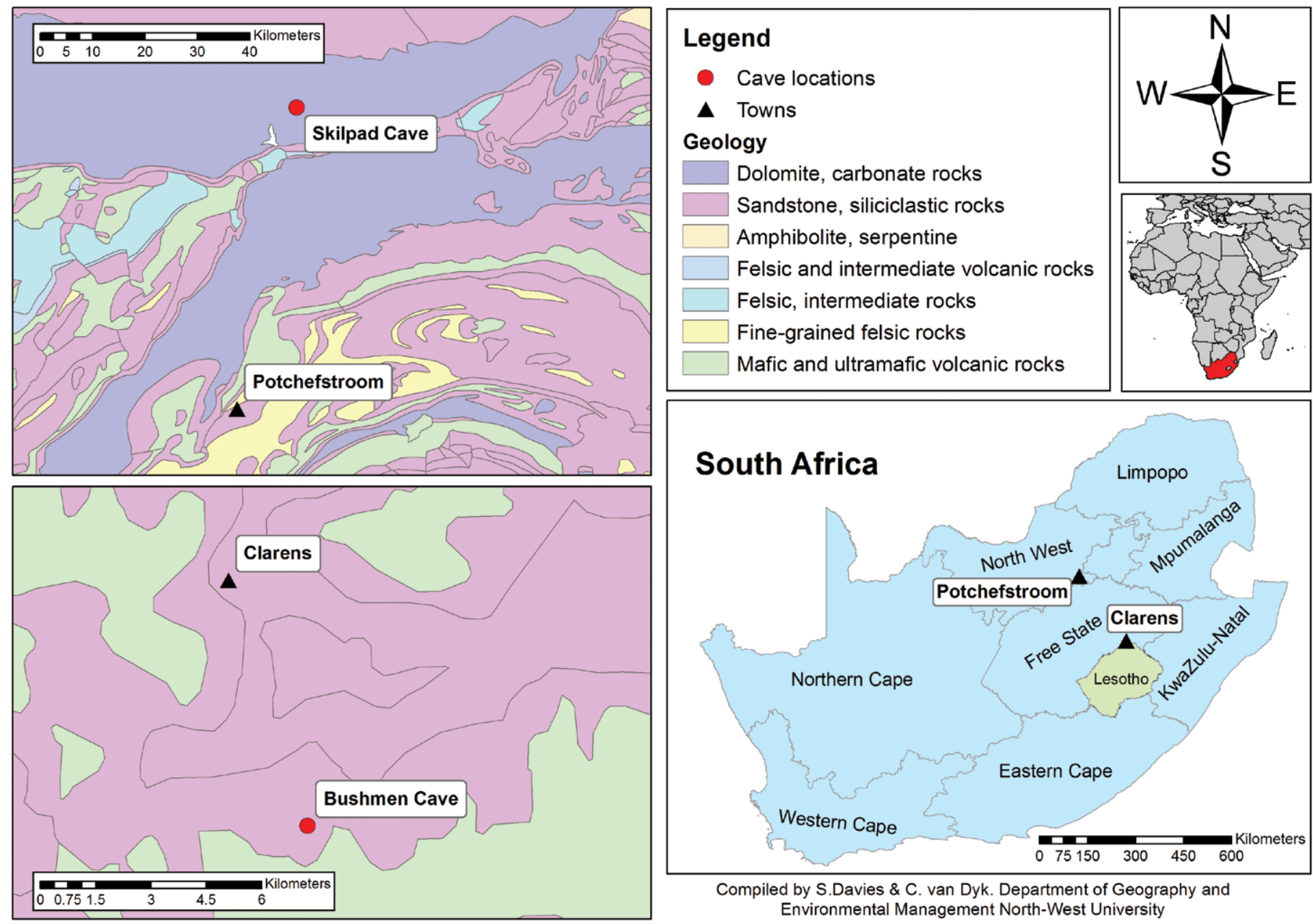

Sandstone, siliciclastic rocks

Amphibolite, serpentine

Felsic and intermediate volcanic rocks

Felsic, intermediate rocks

Mafic and ultramafic volcanic rocks


Compiled by S.Davies \& C. van Dyk. Department of Geography and Environmental Management North-West University

Figure 1. Map of the study areas situated near the towns of Potchefstroom and Clarens, South Africa. Cave locations and underlying geology are indicated on the map.

\section{Sampling and analysis of cyanobacteria and algae}

For cyanobacterial and algological studies, samples were scraped from the surface of cave walls using sterile scalpels and placed into labelled, sterile $60 \mathrm{ml}$ polyethylene containers with airtight lids (Popović et al., 2017). The samples were refrigerated $\left(4^{\circ} \mathrm{C}\right)$ and transported to the North-West University (Potchefstroom campus) the following day. Each sample was divided in two sub-samples. One of the sub-samples was used to inoculate a GBG-11 liquid growth medium (Krüger, 1978) and an $1 \%$ agar plate enriched with the same growth medium. Both the growth medium and agar plate were incubated in a growth chamber with a light intensity of $15 \mu \mathrm{mol} \mathrm{m} \mathrm{m}^{-2} \mathrm{~s}^{-1}$ and a temperature of $21^{\circ} \mathrm{C}$. Cyanobacteria and algae in the growth medium and on the agar were microscopically identified to genus level after a growth phase of two weeks. The second sub-sample was used for immediate cyanobacterial and algal identification to genus level. For both methods, identification was achieved using a Nikon Eclipse 80i light microscope equipped with a Nikon Digital Sight DS-U2 digital camera. Literature used for cyanobacterial and algal identification included John et al. (2002), Wehr and Sheath (2003), Janse van Vuuren et al. (2006), Taylor et al. (2007) and Hindák (2008).

\section{Statistical analysis}

The relationship between abiotic factors (light intensity, temperature, and relative humidity) and cyanobacterial and algal richness at the genus level for each study area (zone) was evaluated with a principal component analysis (PCA) using Canoco 5 software package. To assess the correlation between the respective abiotic factors and cyanobacterial and algal richness, Pearson's correlation coefficient and Spearman's rank correlation coefficient tests were used for parametric and non-parametric data, respectively. The distribution of the errors was considered using the D'Agostino and Pearson omnibus test. Univariate analyses were performed using Graphpad Prism 6 software package and statistical significance was regarded at $P<0.05$. 


\section{Results and Discussion}

\section{Cyanobacterial and algal composition}

In total, 62 epilithic cyanobacterial and algal genera were found in the two studied caves (Table 1). Microscopic investigations revealed that field samples were less diverse than those inoculated and grown in the growth medium and on the agar plates. Photosynthetic prokaryotic organisms were represented by cyanobacteria, also commonly known as blue-green bacteria and sometimes incorrectly referred to as blue-green algae.

Table 1. List of cyanobacteria and algae found in Skilpad and Bushmen caves during the wet (March 2018) and dry (July 2018) seasons. ( $L Z=$ light zone, $T Z$ = twilight zone, $D Z=$ dark zone; $X=$ present).

\begin{tabular}{|c|c|c|c|c|c|c|c|c|c|c|}
\hline \multirow[b]{3}{*}{ Taxa and Authorities } & \multicolumn{6}{|c|}{ Skilpad Cave } & \multicolumn{4}{|c|}{ Bushmen Cave } \\
\hline & \multicolumn{3}{|c|}{ March } & \multicolumn{3}{|c|}{ July } & \multicolumn{2}{|c|}{ March } & \multicolumn{2}{|c|}{ July } \\
\hline & $\mathbf{L Z}$ & TZ & $\mathbf{D Z}$ & $\mathbf{L Z}$ & TZ & $\mathbf{D Z}$ & $\mathbf{L Z}$ & TZ & $\mathbf{L Z}$ & TZ \\
\hline \multicolumn{11}{|l|}{ Prokaryota: } \\
\hline \multicolumn{11}{|l|}{ Cyanobacteria } \\
\hline Anabaena Bory ex Bornet \& Flahault, 1886 & $x$ & $\cdots$ & $\cdots$ & $\cdots$ & $\cdots$ & $\ldots$ & $\cdots$ & $x$ & $\cdots$ & $\ldots$ \\
\hline Aphanocapsa Nägeli, 1849 & $\cdots$ & $\cdots$ & $\cdots$ & $\cdots$ & $\cdots$ & $\cdots$ & $\cdots$ & $\cdots$ & $\cdots$ & $x$ \\
\hline Aphanothece Nägeli, 1849 & $x$ & $\cdots$ & $\cdots$ & $\cdots$ & $\cdots$ & $\cdots$ & $\cdots$ & $x$ & $\cdots$ & $x$ \\
\hline Calothrix Agardh ex Bornet et Flahault, 1886 & $\mathrm{x}$ & $\cdots$ & $\cdots$ & $\cdots$ & $\cdots$ & $\ldots$ & $x$ & $x$ & $\cdots$ & $x$ \\
\hline Chroococcus Nägeli, 1849 & $x$ & $x$ & $\cdots$ & $x$ & $x$ & $\cdots$ & $x$ & $x$ & $x$ & $x$ \\
\hline Gloeocapsa Kützing, 1843 & $\cdots$ & $\cdots$ & $\cdots$ & $\cdots$ & $x$ & $\cdots$ & $\cdots$ & $\cdots$ & $\cdots$ & $x$ \\
\hline Komvophoron Anagnostidis et Komárek, 1988 & $\mathrm{x}$ & $x$ & $\cdots$ & $\cdots$ & $\cdots$ & $\ldots$ & $\cdots$ & $x$ & $x$ & $\cdots$ \\
\hline Lyngbya Agardh ex Gomont, 1892 & $x$ & $\cdots$ & $\cdots$ & $\cdots$ & $\cdots$ & $\cdots$ & $x$ & $x$ & $\cdots$ & $x$ \\
\hline Microcoleus Desmaziéres ex Gomont, 1892 & $x$ & $\cdots$ & $\cdots$ & $\cdots$ & $\cdots$ & $\cdots$ & $x$ & $x$ & $\cdots$ & $\cdots$ \\
\hline Nostoc Vaucher ex Bornet et Flahault, 1886 & $x$ & $x$ & $\cdots$ & $x$ & $\cdots$ & $\cdots$ & $x$ & $x$ & $\cdots$ & $x$ \\
\hline Oscillatoria Vaucher ex Gomont, 1892 & $x$ & $x$ & $\cdots$ & $x$ & $x$ & $\cdots$ & $x$ & $x$ & $x$ & $x$ \\
\hline Petalonema Berkeley ex Correns, 1889 & $\cdots$ & $\cdots$ & $\cdots$ & $\cdots$ & $\cdots$ & $\cdots$ & $\cdots$ & $x$ & $\cdots$ & $x$ \\
\hline Phormidium Kützing ex Gomont, 1892 & $x$ & $x$ & $\cdots$ & $x$ & $x$ & $x$ & $x$ & $x$ & $x$ & $x$ \\
\hline Scytonema Agardh ex Bornet et Flahault, 1886 & $\mathrm{X}$ & $x$ & $\cdots$ & $\mathrm{X}$ & $\cdots$ & $\cdots$ & $\mathrm{x}$ & $x$ & $\mathrm{X}$ & $\mathrm{x}$ \\
\hline
\end{tabular}

\section{Eukaryota:}

Bacillariophyta

Achnanthes Bory, 1822

Achnanthidium Kützing, 1844

Amphora Ehrenberg ex Kützing, 1844

Craticula Grunow, 1868

Cymbella Agardh, 1830

Diadesmis Kützing, 1844

Encyonema Kützing, 1834

Encyonopsis Krammer, 1997

Epithemia Kützing, 1844

Gomphonema Ehrenberg, 1832

Hantzschia Grunow, 1877

Luticola Mann, 1990

Melosira Agardh, 1824

Navicula Bory, 1822

Nitzschia Hassal, 1845

Orthoseira Thwaites, 1848

Pinnularia Ehrenberg, 1843

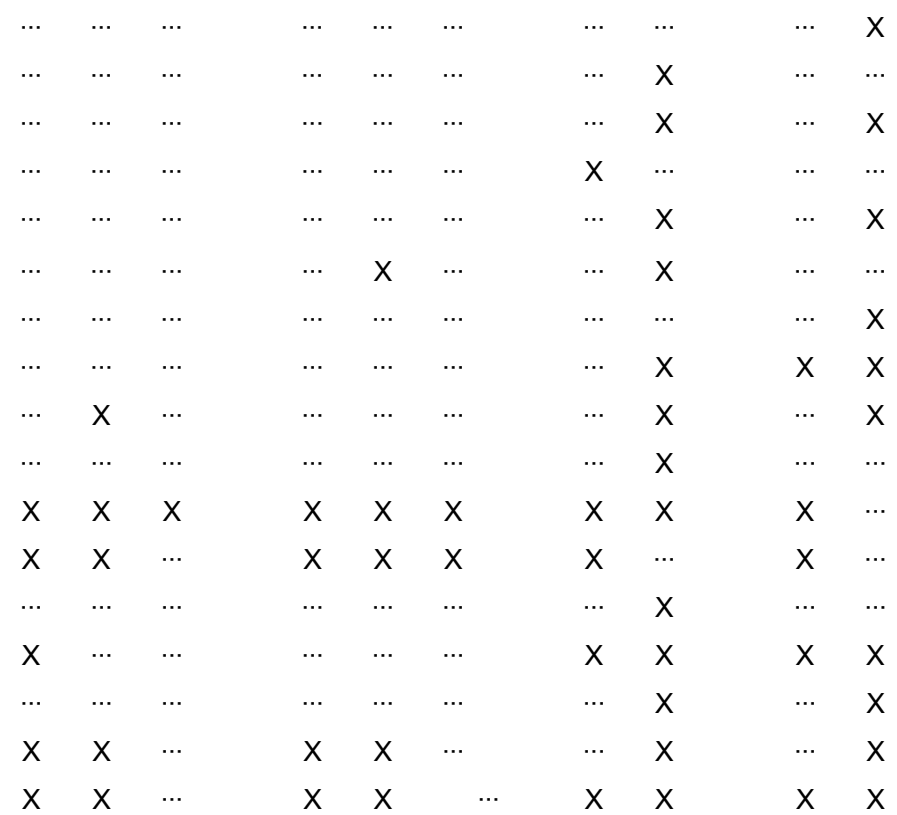


Table 1. (Continued).

\begin{tabular}{|c|c|c|c|c|c|c|c|c|c|c|}
\hline \multirow[b]{3}{*}{ Taxa and Authorities } & \multicolumn{6}{|c|}{ Skilpad Cave } & \multicolumn{4}{|c|}{ Bushmen Cave } \\
\hline & \multicolumn{3}{|c|}{ March } & \multicolumn{3}{|c|}{ July } & \multicolumn{2}{|c|}{ March } & \multicolumn{2}{|c|}{ July } \\
\hline & $\mathbf{L Z}$ & TZ & $\mathbf{D Z}$ & LZ & TZ & $\mathbf{D Z}$ & LZ & $T Z$ & $\mathbf{L Z}$ & TZ \\
\hline
\end{tabular}

Eukaryota:

\section{Bacillariophyta}

Planothidium Round \& Bukhtiyarova, 1996

Rhopalodia Müller, 1895

$\cdots \quad \mathrm{X}$

$\quad \cdots \quad \cdots$

$\begin{array}{lll}\cdots & \cdots & \cdots\end{array}$

$\begin{array}{llll}\cdots & \cdots & \mathrm{X} & \cdots \\ \cdots & \cdots & \cdots & \mathrm{X}\end{array}$

\section{Charophyta}

Actinotaenium (Nägeli) Teiling, 1954

Cosmarium Corda ex Ralfs, 1848

Gonatozygon De Bary, 1858

Hyalotheca Ehrenberg ex Ralfs, 1848

Klebsormidium Silva, Mattox \& Blackwell, 1972

Mesotaenium Nägeli, 1849

Mougeotia Agardh, 1824

Spirogyra Link, 1820

\section{Chlorophyta}

Bracteacoccus Tereg, 1922

Chlamydomonas Ehrenberg, 1833

Chlorella Beyerinck, 1890

Chlorococcum Meneghini, 1842

Chlorosarcinopsis Herndon, 1958

Desmococcus Brand, 1925

Leptosira Borzi, 1883

Microspora Thuret, 1850

Oedogonium Link ex Hirn, 1900

Oocystis Nägeli ex Braun, 1855

Scenedesmus Meyen, 1829

Scotiellopsis Vinatzer, 1975

Stichococcus Nägeli, 1849

Tetracystis Brown \& Bold, 1964

Trebouxia Puymaly, 1924

Trentepohlia Martius, 1817

Ulotrix Kützing, 1833

\section{Ochrophyta}

Botrydium Wallroth, 1815

Eustigmatos Hibberd, 1981

Monodopsis Hibberd, 1981

\begin{tabular}{|c|c|c|c|c|c|c|c|c|c|}
\hline$\ldots$ & $x$ & $\ldots$ & $\ldots$ & $\ldots$ & $\ldots$ & $\ldots$ & $x$ & $x$ & $\ldots$ \\
\hline$x$ & $x$ & $\ldots$ & $\ldots$ & $\ldots$ & $\ldots$ & $\ldots$ & $x$ & $x$ & $\ldots$ \\
\hline$x$ & $x$ & $x$ & $x$ & $x$ & $x$ & $x$ & $x$ & $x$ & $x$ \\
\hline$X$ & $\ldots$ & $x$ & $x$ & $x$ & $x$ & $x$ & $x$ & $x$ & $x$ \\
\hline$\ldots$ & $\ldots$ & $\ldots$ & $x$ & $x$ & $\ldots$ & $\ldots$ & $\ldots$ & $\ldots$ & $\ldots$ \\
\hline$\cdots$ & $x$ & $\ldots$ & $x$ & $\ldots$ & $\cdots$ & $\cdots$ & $\ldots$ & $\cdots$ & $\cdots$ \\
\hline$\cdots$ & $\ldots$ & $\ldots$ & $x$ & $\ldots$ & $\ldots$ & $\ldots$ & $\ldots$ & $\ldots$ & $\ldots$ \\
\hline$\ldots$ & $\ldots$ & $\ldots$ & $\ldots$ & $\ldots$ & $\ldots$ & $\ldots$ & $x$ & $\ldots$ & $\ldots$ \\
\hline$\cdots$ & $x$ & $\ldots$ & $\ldots$ & $\ldots$ & $\ldots$ & $\ldots$ & $x$ & $\ldots$ & $\ldots$ \\
\hline$\cdots$ & $\ldots$ & $\ldots$ & $\ldots$ & $\cdots$ & $\cdots$ & $\cdots$ & $x$ & $\cdots$ & $\cdots$ \\
\hline$\cdots$ & $\ldots$ & $\ldots$ & $\cdots$ & $\ldots$ & $\cdots$ & $x$ & $\ldots$ & $\ldots$ & $\cdots$ \\
\hline$\cdots$ & $x$ & $\ldots$ & $\ldots$ & $\ldots$ & $\ldots$ & $\ldots$ & $\ldots$ & $\ldots$ & $\ldots$ \\
\hline$\cdots$ & $x$ & $\ldots$ & $\ldots$ & $\cdots$ & $\cdots$ & $\cdots$ & $\cdots$ & $\cdots$ & $\cdots$ \\
\hline$\cdots$ & $\ldots$ & $\ldots$ & $\cdots$ & $\ldots$ & $\cdots$ & $\cdots$ & $\ldots$ & $x$ & $\cdots$ \\
\hline$\cdots$ & $x$ & $\ldots$ & $\ldots$ & $\ldots$ & $\ldots$ & $x$ & $\ldots$ & $\ldots$ & $x$ \\
\hline$X$ & $x$ & $\ldots$ & $\ldots$ & $\ldots$ & $\ldots$ & $\cdots$ & $x$ & $\cdots$ & $\cdots$ \\
\hline
\end{tabular}

\section{Rhodophyta}

$\begin{array}{llllll}\ldots & \mathrm{X} & \ldots & \ldots & \ldots & \ldots \\ \ldots & \ldots & \ldots & \mathrm{X} & \ldots & \ldots \\ \mathrm{X} & \ldots & \ldots & \ldots & \ldots & \ldots\end{array}$

...

$\cdots$ 
A total of 14 cyanobacteria genera were found in Bushmen Cave, of which 12 were also present in Skilpad Cave. Aphanocapsa and Petalonema were found in Bushmen Cave, but not Skilpad Cave. The presence of Petalonema alatum in Bushmen Cave represented a first record of this species in Africa (Maree et al., 2018). The most prevalent cyanobacteria included Phormidium (28 sites), Oscillatoria (21 sites), and Nostoc (20 sites). Phormidium, a filamentous cyanobacterium commonly found in caves, was the most frequently encountered genus both in Skilpad and Bushmen caves. Phormidium has long cylindrical filaments with uniseriate trichomes and its dark green to brown sheaths are thin and firm (Czerwik-Marcinkowska and Mrozińska, 2011). It was described from caves throughout Europe, e.g. in Greece (Lamprinou et al., 2013), Spain (Asencio and Aboal, 2000; 2004), Italy (Giordano et al., 2000), Hungary (Claus, 1964), Serbia (Popović et al., 2017) and Poland (Czerwik-Marcinkowska et al., 2015). The second most abundant cyanobacterium was Oscillatoria, regularly found in sub-aerial habitats (Mulec and Kosi, 2008; Sethi et al., 2012). Distribution records of Oscillatoria include caves in Hungary (Claus, 1964), Serbia (Popović et al., 2017) and Slovenia (Mulec and Kosi, 2008). Nostoc, characterized by a gelatinous thallus, was previously found in caves amongst others, in the Czech Republic (Poulíčková and Hašler 2007), Greece (Lamprinou et al., 2012), Israel (Vinogradova et al., 2004), Serbia (Popović et al., 2015), Poland (Czerwik-Marcinkowska et al., 2015), Hungary (Claus, 1964), Turkey (Selvi and Altuner 2007), Slovenia (Mulec and Kosi, 2008) and South Africa (Taylor and Lange-Bertalot, 2013).

Eukaryotic phyla comprised of Bacillariophyta (diatoms; 19 genera), Charophyta (8 genera), Chlorophyta (green algae; 17 genera), Ochrophyta (3 genera), and Rhodophyta (red algae; 1 genus). All five these phyla were identified in Skilpad Cave, while four were present in Bushmen Cave. Chlorophyta and Bacillariophyta represented the richest phyla, in terms of the number of genera, in Skilpad and Bushmen caves, respectively. Czerwik-Marcinkowska and Mrozińska (2011) reported Chlorophyta as one of the dominant phyla in a Polish limestone cave, while Bacillariophyta (diatoms) was also observed by Czerwik-Marcinkowska et al. (2015) in similar environments. The diatom Pinnularia (Phylum Bacillariophyta) was identified at 20 sites and is well-adapted to colonize a wide range of substrates (Macedo et al., 2009). A Polish study reported Pinnularia in five caves (Czerwik-Marcinkowska and Mrozińska, 2011) and it was also found in Israeli caves (Vinogradova et al., 2009). Luticola, another diatom, occurred at 15 sites in Skilpad and Bushmen caves and was previously reported growing on wet rocks and mosses in Slovenian (Mulec and Kosi, 2008), Turkish (Selvi and Altuner 2007), Israeli (Vinogradova et al., 2009) and Serbian (Popović et al., 2017) caves. Chlorella and Chlorococcum are green algae (Phylum Chlorophyta) and both were collected at 17 sites. Chlorella was previously reported from Germany (Claus, 1964; Chang and Chang-Schneider 1991), Czech Republic (Poulíčková and Hašler 2007), Hungary (Claus, 1964), Slovenia (Mulec and Kosi, 2008) and Turkey (Selvi and Altuner 2007), while Chlorococcum have been reported from Polish caves (Czerwik-Marcinkowska and Mrozińska, 2011).

In accordance to the results of this study, Czerwik-Marcinkowska et al. (2015) regarded cyanobacteria, green algae, and diatoms as essential components of cave microflora. Our results clearly indicate that some cyanobacterial and algal genera were singular to Skilpad Cave, while others were only found in Bushmen Cave (Table 1). Although it was not investigated, the distribution of genera may have been influenced by different rock types in the two caves.

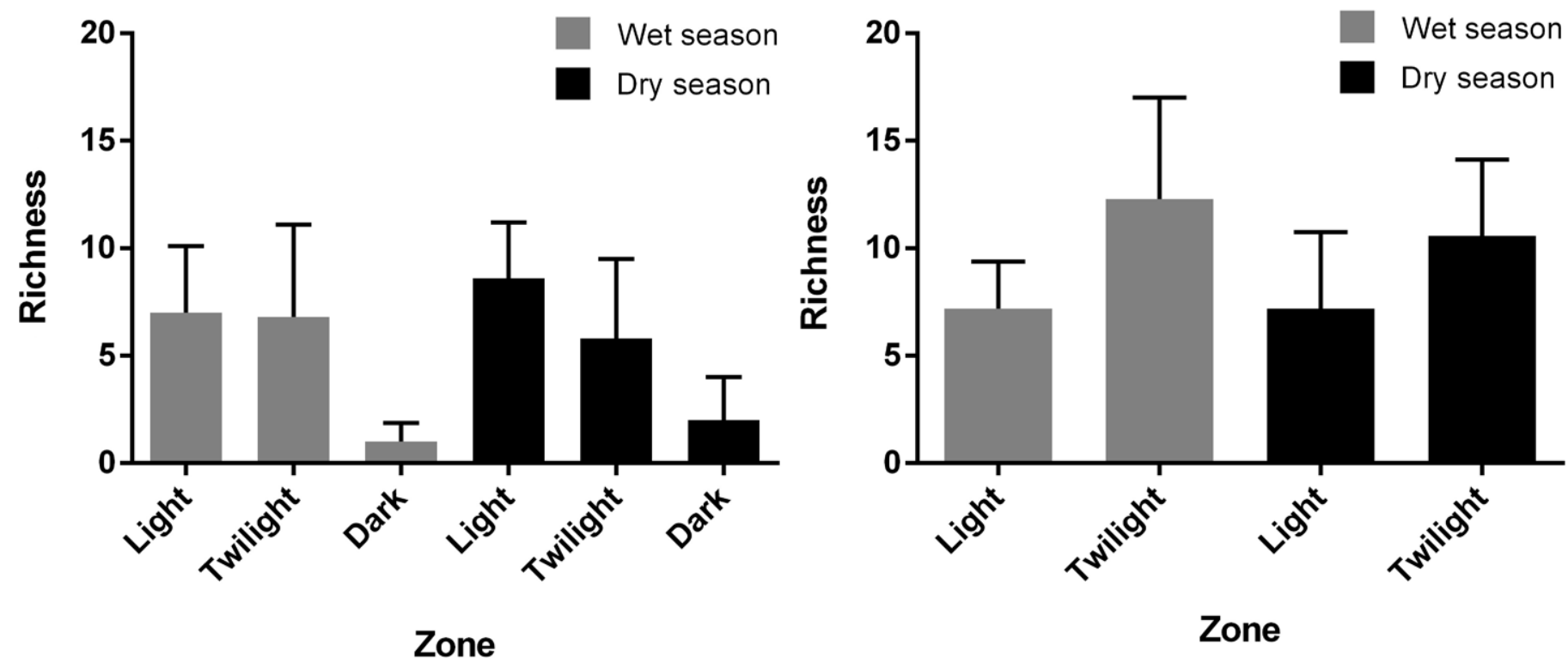

Figure 2. Richness in Skilpad Cave (A) and Bushmen Cave (B). Bars represent the richness in each cave zone during each season. Error bars denote standard deviatation. 


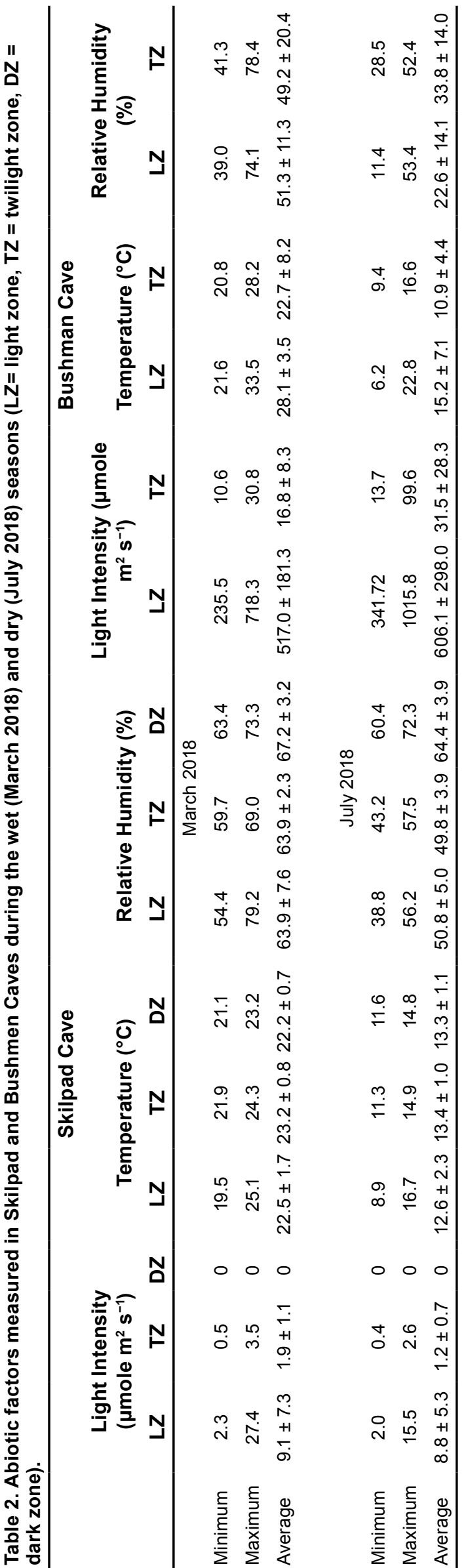

During the wet season, 54 cyanobacterial and algal genera were identified in both caves. This number decreased to 41 during the dry season. When considering genus richness per cave zone per season (Fig. 2), it is evident that the richness decreased from the light zone to the dark zone during both seasons in Skilpad Cave. However, in Bushmen Cave the twilight zone consistently presented the greatest richness. To investigate these findings, the abiotic conditions, in relation to genus richness per cave zone per season, was considered.

\section{Abiotic conditions in relation to epilithic richness}

Results (minimum, maximum, and average values) of the abiotic factors measured during this study are reported in Table 2 . During the wet season (March 2018) variation in Skilpad Cave was observed for light intensity with average values ranging from $9.1 \pm 7.3 \mu \mathrm{mol} \mathrm{m} \mathrm{m}^{2} \mathrm{~s}^{-1}$ (light zone) to $0 \mu \mathrm{mol} \mathrm{m} \mathrm{m}^{-1}$ (dark zone). The same was evidenced for the dry season (July 2018) as average light intensity values ranged

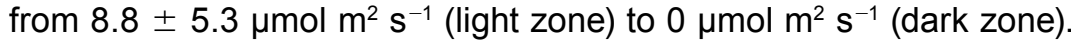
However, variation between the two sampling intervals was especially evident for temperature and relative humidity levels. Bushmen Cave, on the other hand, does not have a dark zone and was exposed to substantially higher light intensity levels. Maximum light intensity lev-

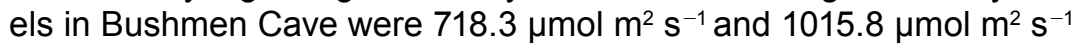
during the wet and dry seasons, respectively, which is likely the result of Bushmen Cave being an overhang rock-shelter characterized by a large North-West facing opening. To the contrary, Skilpad Cave has a narrower sinkhole opening with rock walls, which together with the vegetation surrounding the sinkhole entrance, prevent direct exposure to sunlight. Figure S1 (supplementary material) further illustrates light intensity variation between cave zones and seasons, as well as the difference in exposure between the two studied cave systems.

In order to relate the observed cyanobacterial and algal richness to the abiotic conditions, principal component analysis (PCA) biplots were created. With $90.9 \%$ of the variation explained on the $X(57.4 \%)$ and $Y(33.5 \%)$ axes, Figure $3 \mathrm{~A}$ illustrates that richness in Skilpad Cave was positively related to light intensity and therefore also the light zones during both sampling intervals. The significance of this relationship was further investigated using a correlation coefficient test, which confirmed that a strong, positive correlation $(r=0.7 ; P<0.001)$ existed between richness and light intensity. Furthermore, a moderate, negative correlation $(-0.4 ; P<0.05)$ was evidenced between richness and relative humidity. No significant correlation was observed between richness and temperature in Skilpad Cave. The PCA biplot (Fig. 3B) for Bushmen Cave, with $98 \%$ of the variation explained on the $X(58.2 \%)$ and $Y(39.8 \%)$ axes, illustrated that a negative relationship existed between richness and light intensity. In support of this, a correlation coefficient test revealed that a moderate, negative correlation $(-0.43 ; P<0.05)$ existed between richness and light intensity. No other significant correlations were evidenced in Bushmen Cave.

It is evident that light intensity played a major role in cyanobacterial and algal richness in the studied caves. The positive correlations between richness, light intensity, and relative humidity, as evidenced in Skilpad Cave, have been well documented (Asencio and Aboal, 2000, Poulîčková and Hašler, 2007; Vinogradova et al., 2009). Vinogradova et al. (2009) found that the taxonomic composition of algae is influenced by the gradient of illumination as the number of species drastically decreased from the entrance (46 species) to the deeper reaches (26 species) of an Israeli cave. However, the reason for the negative 

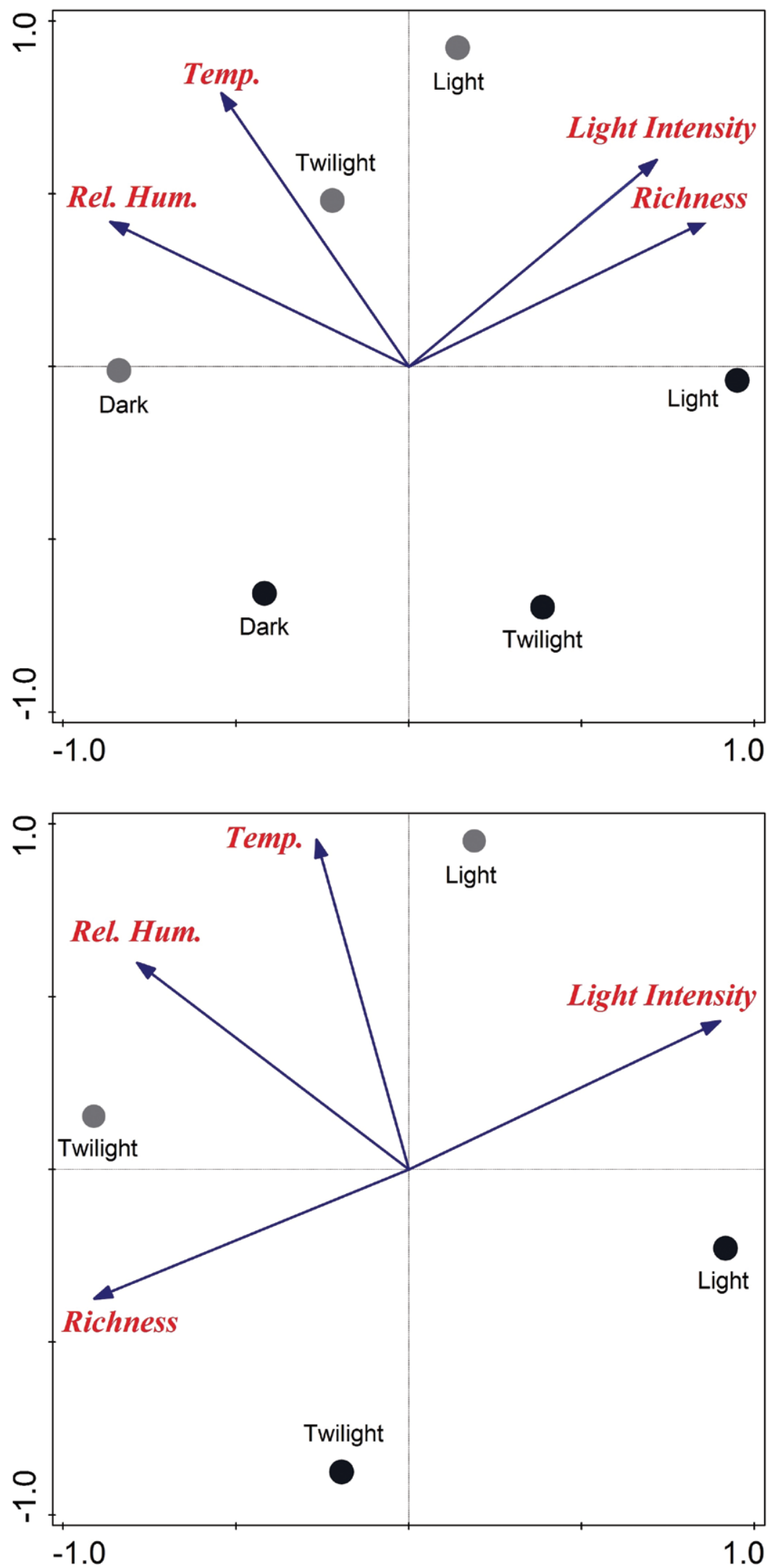

Figure 3. PCA biplot for Skilpad Cave (A) and Bushman Cave (B). Three arrows represent abiotic factors (light intensity, temperature, and relative humidity) and the other arrow represents the cyanobacterial and algal richness. The grey and the black dots represent the cave zones in the wet and dry season respectively. correlation evidenced between richness and light intensity in Bushmen Cave remains unknown. It may, however, be due to huge differences in the light zones of the two caves in terms of morphology and abiotic conditions.

\section{Conclusions}

Limited studies have focused on cyanobacteria and algae in caves located in the southern hemisphere and especially in the southern parts of Africa. Furthermore, only a few scientific works have been published on either cyanobacteria or diatoms associated with South African caves.

During this study two geologically distinct caves in South Africa were studied in terms of their cyanobacterial and algal composition in relation to abiotic environmental variables (light intensity, temperature and relative humidity) considered relevant to the survival of photosynthetic cave microorganisms. A total of 14 cyanobacteria genera were identified from Bushmen Cave, a rock shelter overhang with no dark zone. Twelve of these cyanobacteria genera were identified from Skilpad Cave, a sinkhole entrance cave with a dark zone. The cyanobacterium Petalonema alatum was found in Bushmen Cave and represented the first record of this species in Africa. Phormidium, Oscillatoria and Nostoc were the most common cyanobacteria and occurred in both caves. All three of these genera are also commonly found and widely distributed in northern hemisphere caves.

Algae belonging to five phyla were identified in Skilpad Cave, while representatives of four phyla were found in Bushmen Cave. Chlorophyta (green algae) and Bacillariophyta (diatoms) were represented by a large number of genera in both caves. The most common algae encountered included the diatoms Pinnularia and Luticola and the green algae Chlorella and Chlorococcum. Results of this study corresponded to findings in the northern hemisphere that cyanobacteria, green algae and diatoms are usually the dominant photosynthetic microorganisms found in caves. A higher richness (based on the number of genera) was recorded in the warm, wet season compared to the cold, dry season.

Considering the abiotic conditions, higher light intensities were recorded in Bushmen Cave than Skilpad Cave due to differences in the physical morphology and orientation of the caves. Temperature and relative humidity values also differed between the caves and the 
two sampling intervals. In Skilpad Cave, the genus richness was positively correlated with light intensity, a well-documented relationship. However, an inverse tendency prevailed in Bushmen Cave, a phenomenon that could not be explained.

\section{Acknowledgements}

The authors acknowledge Prof. Jonathan Taylor of the North-West University for his help with diatom identification.

\section{References}

Abdullin, S.R., 2011, Effect of illumination on the distribution of phototrophic organisms in the entrance part of the Shul'gan-Tash Cave: Russian Journal of Ecology, v. 42, p. 249-251. https://doi.org/10.1134/S1067413611030039.

Asencio, A.D., and Aboal, M., 2000, A contribution to knowledge of chasmoendolithic algae in cave-like environments: Archiv fur Hydrobiologie. Supplementband: Algological Studies, v. 98, p.133-151. https://doi.org/10.1127/algol_stud/98/2000/133.

Asencio, A.D., and Aboal, M., 2004, Cell inclusions in the chasmoendolithic Cyanophytes from cave-like environments in Murcia (SE Spain): Archiv fur Hydrobiologie. Supplementband: Algological Studies, v. 113, p. 117-127. https://doi.org/10.1127/1864-1318/2004/0113-0117.

Borderie, F., Alaoui-Sehmer, L., Raouf, N., Bousta, F., Orial, G, Rieffel, D., and Alaoui-Sosse, B., 2011, UV-C irradiation as a tool to eradiate algae in caves: International Biodeterioration and Biodegradation, v. 65, no. 4, p. 579-584.

Büdel, B., Weber, B., Kühl, M., Pfanz, H., Sültemeyer, D., and Wessels, D., 2004, Reshaping of sandstone surfaces by cryptoendolithic cyanobacteria: bioalkalization causes chemical weathering in arid landscapes: Geobiology, v. 2, p. 261-268. https://doi.org/10.1111/j.14724677.2004.00040.x.

Büdel, B., Wessels, D.J., and Mollenhauer, D., 1993, Massenentwicklung von Nostoc cf. microscopicum (CARMICHAEL) Harvey ex Bornet \& Flahault in alkalischem, salzhaltigem Milieu einer Höhle in den Drakensbergen Südafrikas (Golden Gate Highlands National Park) [Mass development of Nostoc cf. microscopicum (CARMICHAEL) Harvey ex Bornet \& Flahault in a sandstone cave in Clarens in the Drakensberg Mountains, South Africa (Golden Gate Highlands National Park)]: Archiv für Protistenkunde, v. 143, no. 1-3, p. 229-235 (in German). https:// doi.org/10.1016/S0003-9365(11)80290-3.

Burger, M., 2013, 1:1,000,000 Scale Geology for South Africa: https://www.arcgis.com/home/webmap/viewer.html?webmap=739c8b22b99b47bb81c2bed660d6c5de [Accessed September 18, 2018].

Busquets, A., Fornós, J.J, Zafra, F., Lalucat, J. and Merino, A., 2014, Microbial communities in a coastal cave: Cova des Pas de Vallgornera (Mallorca, Western Mediterranean): International Journal of Speleology, v. 43, no. 2, p. 205-216. https://doi.org/10.5038/1827-806X.43.2.8

Cennamo, P., Marzano, C., Ciniglia, C., Pinto, G., Cappelletti, P., Caputo, P., and Pollio, A., 2012, A survey of the algal flora of anthropgenic caves of Campi Flegrei (Naples, Italy) archaelogical district: Journal of Cave and Karst Studies, v. 74, no. 3, p. 243-250. http://dx.doi. org/10.4311/2011JCKS0194.

Chang, T.P., and Chang-Schneider, H., 1991, Algen in vier süd-deutschen Höhlen [Algae in four southern Germany caves]: Berichte der Bayerischen Botanischen Gesellschaft, v. 62, p. 221-229 (in German).

Claus, G., 1964, Algae and their mode of life in the Baradla Cave at Aggtelek II: International Journal of Speleology, v. 1, p. 13-17. http://dx.doi. org/10.5038/1827-806X.1.1.2.

Culver, D.C., Pipan, T., 2009, The Biology of Caves and Other Subterranean Habitats: Oxford University Press, Oxford, 254 p.

Czerwik-Marcinkowska, J., 2013, Observations on aerophytic cyanobacteria and algae from ten caves in the Ojców National Park: Acta Agrobotanica, v. 66, no. 1, p. 39-52. https://doi.org/10.5586/aa.2013.005.

Czerwik-Marcinkowska, J., and Mrozińska, T., 2011, Algae and cyanobacteria in caves of the Polish Jura: Polish Botanical Journal, v. 56, no. 2, p. 203-243.

Czerwik-Marcinkowska, J., Wojciechowska, A., and Massalski, A., 2015, Biodiversity of limestone caves: Aggregations of aerophytic algae and cyanobacteria in relation to site factors: Polish Journal of Ecology, v. 63, no. 4, p. 481-499. http://dx.doi.org/10.3161/15052249P JE2015.63.4.002.

Czerwik-Marcinkowska, J., Zwijacz-Kozica, T., Pusz, W., and Wojciechowska, A., 2019, The relationship between presence of brown bear (Ursus arctos) and diversity of airbone algae and cyanobacteria in the Glowoniowa Nyza cave, Tartra Mountains, Poland: Journal of Cave and Karst Studies, v. 81, no.1, p. 57-67. http://dx.doi.org/10.4311/2018MB0121.

Ducarme, X., Wauthy, G., André, H.M., and Lebrun, P., 2004, Survey of mites in caves and deep soil and evolution of mites in these habitats: Canadian Journal of Zoology, v. 82, no. 6, p. 841-850. https://doi.org/10.1139/z04-053.

Falasco, E., Ector, L., Isaia, M., Wezel, C.E., Hofmann, L., Bona, F., 2014, Diatom flora in subterranean ecosystems: A review: International Journal of Speleology, v. 43, no. 3, p. 231-251. https://doi.org/10.5038/1827-806X.43.3.1

Gainutdinov, I., Abdullin, S., Sharipova, M.Y., and Dobivik, I.E., 2017, Cyanobacteria and algae in some caves of the Bashkirskiyi Ural Biosphere Reserve (Southern Urals, Bashkortostan Republic, Russia): Cave and Karst Science, v. 44, no. 3, p. 119-126.

Giordano, M., Mobili, F., Pezzoni, V., Hein, M.K., and Davis, J.S., 2000, Photosynthesis in the caves of Frasassi (Italy): Phycologia, v. 39, no. 5, p. 384-389. https://doi.org/10.2216/i0031-8884-39-5-384.1.

Golubić, S., 1967, Algenvegetation der Felsen. Eine Ökologische Algenstudieimdinarischen Karstgebiet [Algae vegetation of rocks. An ecological algae study in the Dinaric kars area], in Elster, H.J., and Ohle, W., eds., Die Binnengewässer [The inland waters], E. Schweizerbart'sche Verlagsbuchhandlung, Stuttgart, W. Germany, 183 p. (in German).

Grobbelaar, J.U., 2000, Lithophytic algae: a major threat to the karst formation of show caves: Journal of Applied Phycology, v. 12, pp. $309-315$.

Hernandéz-Mariné, M., and Canals, T., 1994, Herpyzonema pulverulentum (Mastigocladaceae), a new cavernicolous atmophytic and lime-incrusted cyanophyte: Algological Studies/Archiv für Hydrobiologie, Supplement, v. 105, no. 75, p. 123-136.

Hindák, F., 2008, Colour Atlas of Cyanophytes: Veda, Bratislava, Publishing House of the Slovak Academy of Sciences, 256 p.

Humphreys, W.F., 2000, Background and glossary, in Wilkens, H., Culver, D.C., and Humphreys, W.F., Subterranean ecosystems, Ecosystems of the World: Amsterdam, Elsevier, p. 3-14.

Janse van Vuuren, S., Taylor, J.C., Gerber, A., and Van Ginkel, C., 2006, Easy identification of the most common freshwater algae. A guide for the identification of microscopic algae in South Arican freshwaters: North-West University and Department of Water Affairs and Forestry, 200 p.

John, D.M., Whitton, B.A., and Brook, A.J., 2002, The freshwater algal flora of the British isles: Cambridge, Cambridge University Press, 720p. 
Johnson, M., 1991, Sandstone petrography, provenance and plate tectonic setting in Gondwana context of the south eastern Cape-Karoo Basin: South African Journal of Geology, v. 94, no. 2, p. 137-154.

Kasso, M., Balakrishnan, M., 2013, Ecological and economic importance of bats (Order Chiroptera): International Scholarly Research Notices, Biodiversity, Article ID 187415, 9 p. http://dx.doi.org/10.1155/2013/187415.

Khan, M., Karmakar, R., Das, B., Diba, F., Razu, M.H., 2016. Heterotrophic growth of micro algae. In: Recent Advances in Microalgal Biotechnology, Publisher: OMICS Group eBooks. Editors: Dr. Jin Liu, Dr. Zheng Sun, Dr. Henri Gerken: pp. 1-18.

Krüger, G.H.J., 1978, The effect of physio-chemical factors on the growth relevant to the mass culture of Microcystis under sterile conditions [Ph.D. thesis]: Bloemfontein, South Africa, University of the Orange Free State, $134 \mathrm{p}$.

Lamprinou, V., Danielidis, D.B., Economou-Amilli, A., and Pantazidou, A., 2012, Distribution survey of cyanobacteria in three Greek caves of Peloponnese: International Journal of Speleology, v.41, no. 2, p. 267-272. https://doi.org/10.5038/1827-806X.41.2.12.

Lamprinou, V., Pantazidou, A., Papadogiannaki, G., Radea, C., and Economou-Amili, A., 2009, Cyanobacteria and associated invertebrates in Leontari cave: Fottea, v. 9, no. 1, p. 155-164. https://doi.org/10.5507/fot.2009.014.

Lamprinou, V., Skaraki, K., Kotoulas, G., Anagnostidis, K., Economou-Amilli, A., and Pantazidou, A., 2013, A new species of Phormidium (Cyanobacteria, Oscillatoriales) from three Greek caves: morphological and molecular analysis: Fundamental and Applied Limnology, v. 182, no. 2, p. 109-116. https://doi.org/10.1127/1863-9135/2013/0323.

Lee, N.M., Meisinger, D.B., Aubrecht, R., Kovacik, L., Saiz-Jimenez, C., Baskar, S., Baskar, R., Liebl, W., Porter, M., and Summers-Engel, A., 2012, Life in caves and karst environments, in Bell, E.M., ed., Life at Extremes: Environments, Organisms and Strategies for Survival, CABI Publishing, Wallingford, UK, p. 320-344. https://doi.org/10.1079/9781845938147.0320.

Macedo, M.F., Miller, A.Z., Dionísio, A., and Saiz-Jimenez, C., 2009, Biodiversity of cyanobacteria and green algae on monuments in the Mediterranean Basin: an overview: Microbiology, v. 155, no. 11, p. 3476-3490. http://dx.doi.org/doi:10.1099/mic.0.032508-0.

Maree, L., Janse van Vuuren, S., Levanets, A., and Taylor, J., 2018, First record of a cyanobacterium Petalonema alatum (Borzì ex Bornet \& Flahault) Correns (Cyanobacteria, Scytonemataceae) in Africa: Checklist, v. 14, no. 5, p. 827-832. https://doi.org/10.15560/14.5.827.

Martinčič, A., Vrhovšek, D., Batič, F., 1981, Flora v jamah z umetno osvetlitvijo [Flora in caves with artificial lights]: Biol. Vestnik, v. 29, no. 2, p. 27-56 (in Slovenian).

Monro, A.K., Bystriakova, N., Fu, L., Wen, F., Wei, Y., 2018, Discovery of a diverse cave flora in China. PLoS ONE 13(2): e0190801. https://doi. org/10.1371/journal.pone.0190801

Mucina, L., Hoare, D,B,, Lötter, M.C., Du Preez, P.J., Rutherford, M.C., Scott-Shaw, C.R., Bredenkamp, G.J., Powrie, L.W., Scott, L., Camp, K.G.T., Cilliers, S.S., Bezuidenhout, H., Mostert, T.H., Siebert, S.J., Winter, P.J.D., Burrows, J.E., Dobson, L., Ward, R.A., Stalmans, M., Oliver, E.G.H., Siebert, F., Schmidt, E., Kobisi, K., and Kose, L., 2006, Grassland Biome, in Mucina, L., and Rutherford, M.C., eds., The vegetation of South Africa, Lesotho and Swaziland: Strelitzia 19, South African National Biodiversity Institute (SANBI), Pretoria, p. 349-437.

Mulec, J., and Kosi, G., 2008, Algae in the aerophytic habitat of Račiške ponikve cave (Slovenia): Natura Sloveniae, v. 10, no. 1, p. 39-49.

Mulec, J., Kosi, G., and Vrhovšek, D., 2008, Characterization of cave aerophytic algal communities and effects of irradiance levels on production of pigments: Journal of Cave and Karst Studies,v. 70, no. 1, p. 3-12.

Pedersen, K., 2000, Exploration of deep intraterrestrial microbial life: current perspective: MiniReview: FEMS Microbiology Letters, v. 185, no. 1, p. 9-16. https://doi.org/10.1016/S0378-1097(00)00061-6.

Pipan, T., 2005, Epikarst - a promising habitat: copepod fauna, its diversity and ecology: a case study from Slovenia (Europe): ZRC Publishing, Karst Research Institute at ZRC SAZU, Postojna-Ljubljana, Slovenia, p. 101.

Popović, S., Simić, G.V.S, Stupar, M., Unković, N., Krunić, O., Savić, N., and Grbić, M.L., 2017, Cave biofilms: characterization of phototrophic cyanobacteria and algae and chemotrophic fungi from three caves in Serbia: Journal of Cave and Karst Studies, v. 79, no. 1, p. 10-23. http:// dx.doi.org/10.4311/2016MB0124.

Popović, S., Simić, G.V.S., Stupar, M., Unković, N., Predojević, D., Jovanović, J., and Grbić M.L., 2015, Cyanobacteria, algae and microfungi present in biofilm from Božana Cave (Serbia): International Journal of Speleology, v.44, no. 2, p. 141-149. http://dx.doi.org/10.5038/1827806X.44.2.4.

Poulîčková, A., and Hašler, P., 2007, Aerophytic diatoms from caves in central Moravia (Czech Republic): Preslia, v. 79, no. 2, p.185-204.

Sambamurty, A.V.S.S., 2010. A Textbook of Algae. New Delhi: I.K. International Publishing House Pvt Ltd, p. 23-31.

Selvi, B., and Altuner, Z., 2007, Algae of Ballica Cave (Tokat-Turkey): International Journal of Natural and Engineering Sciences. v. 1, no. 3, p. 99-103.

Sethi, S.K., Samad, L.K., and Adhikary, S., 2012, Cyanobacteria and micro-algae in biological crusts on soil and sub-aerial habitats of eastern and north eastern region of India: Phykos, v. 42, no. 1, p. 1-9.

Simon, K.S., Benfield, E.F., and Macko, S.A., 2003, Food web structure and the role of epilithic films in cave streams: Ecology, v. 9, no. 84, p. 2395-2406. https://doi.org/10.1890/02-334.

Smarž, J., Kováč, L., Mikeš, J., Lukešová, A. 2013. Microwhip scorpions (Palpigradi) feed on heterotrophic cyanobacteria in Slovak caves - A curiosity among Arachnida. PLoS One, 8(10): e75989. https://doi.org/10.1371/journal.pone.0075989.

Souza Silva, M., Parentoni Martins, R., Lopes Ferreira, R., 2011, Trophic dynamics in a neotropical limestone cave: Subterranean Biology, v. 9 , pp. 127-138. https://doi.org/10.3897/subtbiol.9.2515.

Taylor, J.C., Harding, W.R., and Archibald, CGM, 2007, An illustrated guide to some common diatom species from South Africa: WRC Report No. TT 282/07, Water Research Commission, Pretoria, 178 p.

Taylor, J.C., and Lange-Betalot, H., 2013, Cholnokyella aerophila J.C. Taylor \& Lange-Bertalot gen. et spec. nov. A new diatom (Bacillariophyceae) from sandstone caves in South Africa: Nova Hedwigia, v. 97, no. 3-4, p. 295-304. https://doi.org/10.1127/0029-5035/2013/0118.

Vinogradova, O.N., Nevo, E., and Wasser, S.P., 2009, Algae of the Sefunim Cave (Israel): Species diversity affected by light, humidity and rock stresses: International Journal on Algae, v. 11, no. 2, p. 99-116. https://doi.org/10.1615/InterJAlgae.v11.i2.10.

Wattez, J., Courty, M.A., Macphail, R.I., 1990, Burnt organo-mineral deposits related to animal and human activities in prehistoric caves: Developments in Soil Science, v. 19, pp. 431-439. https://doi.org/10.1016/S0166-2481(08)70358-1.

Wehr, J.D., and Sheath, R.G., 2003, Freshwater algae of North America, ecology and classification: Boston, Academic Press, 918 p.

Wessels, D.C.J., and Büdel, B., 1995, Epilithic and cryptoendolithic cyanobacteria of Clarens Sandstone Cliffs in the Golden Gate Highlands National Park, South Africa: Plant Biology, v. 108, no. 3, p. 220-226. https://doi.org/10.1111/j.1438-8677.1995.tb00853.x.

World Weather Online, 2018. https://www.worldweatheronline.com [Accessed September 26, 2018]. 